\title{
IMPLEMENTATION OF TECHNOLOGICAL APPROACH IN TRAINING OF THE FUTURE TACHERS OF MATHEMATICS
}

\section{РЕАЛІЗАЦІЯ ТЕХНОЛОГІЧНОГО ПІДХОДУ У НАВЧАННІ МАЙБУТНІХ УЧИТЕЛІВ МАТЕМАТИКИ}

\author{
Valentine BEVZ, \\ Doctor of Pedagogical Sciences, \\ Professor \\ Валентина БЕВ3, \\ https://orcid.org/0000-0001-8508-1118 \\ доктор педагогічних наук, \\ профресор, \\ bevzvalya@gmail.com \\ National Pedagogical Dragomanov \\ University \\ 9 Pirogova St., \\ Kiev, 01601 \\ Tetiana HODOVANIUK, \\ Candidate of Pedagogical Sciences, \\ Associate Professor \\ https://orcid.org/0000-0002-7087-7102 \\ tgodovanyuk@ukr.net \\ Vitalii DUBOVYK, \\ PhD student \\ https://orcid.org/0000-0003-0717-4719 \\ vitalij.dybovuk@gmail.com \\ Pavlo Tychyna Uman State \\ Pedagogical University \\ 2 Sadova St., \\ Uman, Cherkasy region, 20300 \\ Національний педагогічний \\ університет \\ імені М.П. Драгоманова \\ вул. Пирогова, 9, м. Київ, 01601 \\ Тетяна ГОДОВАНЮК, \\ кандидат педагогічних наук, доцент \\ Original manuscript received: October 14, 2019 \\ Revised manuscript accepted: December 11, 2019
}

\section{ABSTRACT}

In the information filled world, students need to pass a large amount of information and differentiate it in accordance to the requirements, necessities and preferences of the subjects of the educational process. That is why the dominant feature of educational and cognitive activity of the future mathematics teacher should be a deep knowledge and understanding of all mechanisms of the learning process, in particular adaptability - the achievement of the goal based on the use of a rational system of actions of teachers and students.

One of the first technologies in education - programmed learning - appeared in the middle of the last century. The distinctive features of this technology are the clear formulation of the educational goal and the algorithm for its achievement. Another 
technology has its origins in the middle of the last century - it is a technology of advanced learning. The basic idea of this technology is to create a comfortable learning environment and conditions for successful learning. Both of these technologies are pedagogical technologies based on the electiveness of management and organization of the learning process.

Independent work of students is of particular relevance in the process of preparation of future teachers, since they have to promote this kind of educational and cognitive activity in the work with future students in general secondary education institutions. Therefore, in the context of the study, the issue of organizing students; independent work on the basis of advanced technology using ICT was considered.

In order to intensify the preparation of the future Mathematics teachers on the basis of effective independent work of students, it is proposed to modernize and adapt two known technologies for the student audience: advanced and programmed learning. The main idea is to open up online courses and other services (podcasts, interactive timeline, quest guides, etc.) for students to independently work on separate educational topics, ahead of their study in the classroom.

Key words: future teachers of Mathematics, pedagogical technologies, independent work, perspective-advanced technology, programmed teaching, podcasts, timeline.

Вступ. В умовах функціонування інформаційного суспільства та прискорення процесів оновлення інформації нагальною потребою стає модернізація системи освіти, зокрема педагогічної, на основі змін пріоритетних цілей навчання та способів його організації. Освітній процес у вищій школі - це спеціально організована та спланована взаємодія викладачів і студентів, спрямована на розвиток особистості студента та його підготовку до професійної діяльності. У процесі такої взаємодії, тобто під час навчання, відбувається «передача» накопиченого попередніми поколіннями знань і соціального досвіду, їх трансформація та розширення. Сучасні освітні процеси - складні та динамічні, оскільки на них впливає багато різних чинників та їх неочікуваних поєднань. Об'єктивними серед цих чинників $є$ зовнішні - умови, форми та засоби навчання, зміст і методи навчання, рівень професійної підготовки викладача, соціальне оточення студента тощо. Суб'єктивні чинники пов'язані з особистісними рисами студентів - характер, мислення, пам'ять, пізнавальні можливості, здібності, мотивація учіння, попередній досвід, рівень знань, стиль навчальнопізнавальної діяльності тощо, а тому $€$ внутрішніми. Ефективність педагогічної діяльності та її вдосконалення визначаються, крім іншого, вибором методологічних підходів до організації освітнього процесу та створенням відповідних умов для їх реалізації.

У педагогічній науці та практиці на цей час накопичилася велика кількість теоретичних і практичних здобутків, які стосуються визначення та впровадження сучасних методологічних підходів для організації та здійснення навчання майбутніх учителів математики в педагогічному університеті. На нашу думку, найбільш ефективними в сучасних умовах $€$ : системний, компетентнісний, середовищний, професійно-особистісний, індивідуально-творчий і технологічний. 
В інформаційному світі під час навчання студенти мають за невеликі проміжки часу пропускати через себе велику кількість інформації та диференціювати її відповідно до вимог, потреб і бажань суб'єктів освітнього процесу. Саме тому домінантною ознакою навчальнопізнавальної діяльності майбутнього вчителя математики має стати глибоке знання та розуміння всіх механізмів процесу навчання, тобто технологічність - досягнення поставленої мети на основі використання раціональної системи дій викладача і студентів (вчителя та учнів).

Одна з перших технологій в освіті - програмоване навчання з'явилася в середині минулого століття. Характерними рисами цієї технології є чітке формулювання навчальної мети та надання алгоритму її досягнення. Використання цієї технології уможливлює самостійне індивідуальне навчання для кожного студента відповідно до індивідуальних особливостей і здібностей. Слід зазначити, що технологія програмованого навчання має свої переваги і недоліки, а тому не завжди реалізовувалася в повну силу. Сьогодні в умовах інформатизації освіти технологія програмованого навчання знову набуває актуальності та розвитку, зокрема за допомогою відкритих онлайн курсів та інших сервісів.

Ще одна технологія бере свій початок 3 середини минулого століття - це технологія перспективно-випереджального навчання. Основна ідея цієї технології - створення комфортного освітнього середовища й умов для забезпечення успіху в навчанні. Щоб запобігти об'єктивним труднощам засвоєння навчального матеріалу, пропонується випереджати його введення в процес навчання. Сьогодні дещо в трансформованому вигляді вона “відроджується" в елементах перевернутого навчання.

Обидві ці технології відносяться до педагогічних на основі ефективності управління та організації процесу навчання. Управління в освітньому процесі - це внутрішній та зовнішній вплив на суб'єктів навчання, що забезпечує цілеспрямований розвиток кожного 3 них. Володіння технологією управління процесом навчання студентів $є$ однією із складових діяльності викладача вищої школи. Організація освітнього процесу в 3ВО та управління навчально-пізнавальною діяльністю студентів у сучасних умовах функціонування суспільства та системи освіти $€$ визнаною проблемою. Одним із способів її розв'язання може стати впровадження у процес підготовки майбутніх учителів математики технологій на основі ефективності управління й організації процесу навчання.

Проблему використання педагогічних технологій в освітньому процесі досліджували В. Безпалько, І.Герасименко, С. Гончаренко, М. Гриньова, І. Дичківська, О. Жерновникова, І. Зязюн, М. Кларін, А. Нісімчук, О. Падалка, О. Пєхота, І. Підласий, Г. Селевко, С. Сисоєва, Ю. Триус, О. Шпак та багато інших науковців. Вони розглядали історію перенесення терміна “технологія" в педагогіку, вивчали зарубіжний досвід, описували термінологічні аспекти проблеми, висвітлювали загальні та конкретні питання про види освітніх технологій та їх характерні ознаки, досліджували особливості впровадження інноваційних технологій у процес 
навчання математики та інших навчальних дисциплін тощо.

Наприклад, С. Гончаренко, розкриваючи зміст поняття технологія навчання, послуговується означенням ЮНЕСКО, а саме: "Це в загальному розумінні системний метод створення, застосування й визначення всього процесу навчання і засвоєння знань з урахуванням технічних і людських ресурсів та їх взаємодії, який ставить своїм завданням оптимізацію освіти" (Гончаренко, 1997: 331).

Детальний аналіз технологічного підходу до побудови навчання в західній педагогіці минулого століття зробив М. Кларін і у такий спосіб подав загальний принцип “технологічної" побудови навчання (орієнтація на чітко і детально визначені цілі) та її вихідне положення (для кожної мети є правило, процедура, алгоритм або еквівалентний їм набір процедур). Він також звернув увагу на те, що інструментальна спрямованість “педагогічної технології" визначає ії широкі можливості в побудові різних систем навчання на основі різних наборів навчальних процедур (Кларін, 1989).

Проте найповніше визначення освітніх технологій було отримано від Barbara B. Seels та Rita C. Richey (1994), які писали: “Технологія навчання це теорія і практика проєктування, розробки, використання, управління та оцінки процесів і ресурсів для навчання" (Seels \& Richey, 1994: 9)

Розвиток "педагогічних технологій” сьогодні тісно пов'язаний 3 упровадженням інформаційно-комунікаційних технологій навчання. Про актуальність їх використання наголошують вітчизняні та зарубіжні педагоги: Гарі Біттер (Bitter, G. G.), В. Биков, Ліза Брейт (Breit L.), М. Жалдак, Робін Кей (Robin H. Kay), Б. Грісмар (Brian A. Grismore), Н. Морзе, Меліса Пірсон (Pierson M. Е.), С. Раков, Ю. Триус, Марта Віске (Wiske M. S.) та інші.

Так, Ю. Триус, подаючи загальну характеристику інноваційних інформаційних технологій у навчанні математичних дисциплін, наголошує, що їх використання надасть можливість активізувати навчально-пізнавальну і науково-дослідну діяльність студентів, підвищити рівень їхньої математичної і професійної підготовки, розкрити творчий потенціал і збільшити роль самостійної та індивідуальної роботи за рахунок застосування новітніх інформаційних та педагогічних технологій (Триус, 2005).

Зарубіжні дослідники, наприклад, Гарі Біттер і Меліса Пірсон (2005), а також Марта Віске та ін. (2005), вказують на підвищення ефективності навчання за рахунок використання навчальних технологій. У навчальних середовищах, де інтегрована освітня технологія, і студенти, і викладачі відчувають переваги від його використання. У цьому контексті Г Біттер і М. Пірсон на основі проведеного аналізу ситуації заявили, що “студенти, які користуються технологіями, мають скромні, але позитивні переваги в результатах навчання над тими студентами, які не використовували технологій" (Bitter \& Pierson, 2005: 107).

Зарубіжні дослідники висловлюють одностайну думку про те, що технологія забезпечує мотивацію до здійснення навчання студентами та викладачами, які $€$ користувачами цієї технології. Встановлено (Wiske, 
Серія: Педагогічні науки. - Вип.3. - Бердянськ : БДПУ, 2019. - 453 с.

Franz, \& Breit, 2005), що викладання, навчання та технології працюють синергетично для забезпечення ефективної передачі знань, оскільки освітня технологія допомагає викладачам створювати контексти навчання, які раніше були неможливі в умовах традиційних методів навчання.

Питання про необхідність упровадження освітніх технологій для навчання, їх види, переваги у використанні, а також конкретні практичні рекомендації щодо оцінювання ресурсів та інформаційної грамотності, підвищення кваліфікації висвітлює американський дослідник Brian A. Grismore (2012). Він, зокрема, застерігає, що педагогам потрібно переконатися, чи справді ця технологія посилює процес навчання і не $€$ випадково обраним засобом навчання. Технологія повинна сприяти та вдосконалювати навчання студентів, а не використовуватися лише заради збереження зайнятості студентів (Grismore, 2012: 3).

Отже, використання технологічного підходу визнано ефективним для навчання багатьма дослідниками, а тому його варто впроваджувати в підготовку майбутніх учителів математики. Актуальність цього підходу особливо зростає в умовах інфрорматизації та модернізації освітнього процесу.

Mema cmammi - показати, як за допомогою IKT можна реалізувати технологічність у підготовці майбутніх учителів математики на основі запровадження осучасненої технології перспективно-випереджального навчання.

Методи та методики дослідження. В умовах стрімкого розвитку інформаційно-комунікаційних технологій суттєво змінюється їх місце і значення у в освітньому процесі. Зміни відбуваються й в організації підготовки майбутніх учителів математики. Для дослідження можливостей використання осучасненої технології перспективно-випереджального навчання під час підготовки майбутніх учителів математики використовувалися такі методи: спостереження за перебігом освітнього процесу та способами діяльності його суб'єктів, опитування студентів і викладачів і бесіди з ними, порівняння навчальних планів і програм.

Було проаналізовано навчальні плани кількох педагогічних i класичних університетів і встановлено (на прикладі вивчення курсу “Методика навчання математики"), що значна частина навчального часу відводиться на самостійну роботу студентів (таблиця 1).

Таблиця 1

Порівняльна таблиця кількості годин, передбачених на дисципліну "Методика навчання математики"

\begin{tabular}{|c|c|c|c|c|c|c|c|c|}
\hline $\begin{array}{l}\text { № } \\
\text { 3/ח }\end{array}$ & $\begin{array}{l}\text { Назва закладу вищої } \\
\text { освіти }\end{array}$ & O를 & $\begin{array}{l}\text { 응 } \\
\text { d0 } \\
\text { D. }\end{array}$ & 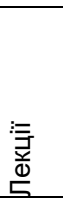 & 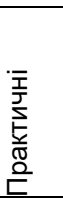 & $\begin{array}{l}\overline{1} \\
\text { 응 } \\
\frac{1}{0} \\
0 \\
0 \\
0 \\
\pi \\
\frac{\pi}{5}\end{array}$ & 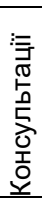 & 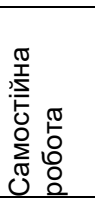 \\
\hline 1. & $\begin{array}{l}\text { Національний педагогічний } \\
\text { університет } \\
\text { М. П. Драгоманова } \\
\end{array}$ & $5-8$ & 450 & 118 & 134 & - & - & $\begin{array}{c}198 \\
(44 \%)\end{array}$ \\
\hline 2. & Уманський & $6-8$ & 390 & 96 & 80 & 64 & - & 240 \\
\hline
\end{tabular}


Наукові записки БДПУ (http://bdpu.org/pedagogy/ua/)

\begin{tabular}{|c|c|c|c|c|c|c|c|c|}
\hline & $\begin{array}{l}\text { педагогічний університет } \\
\text { імені Павла Тичини }\end{array}$ & & & & & & & $(61,5 \%)$ \\
\hline 4. & $\begin{array}{l}\text { Бердянський державний } \\
\text { педагогічний університет }\end{array}$ & $\begin{array}{l}6 \\
7\end{array}$ & 270 & 78 & 30 & 36 & - & $\begin{array}{c}126 \\
(46,7 \%)\end{array}$ \\
\hline 5. & $\begin{array}{lr}\text { Вінницький } & \text { державний } \\
\text { педагогічний } & \text { університет } \\
\text { iмені } & \text { Михайла } \\
\text { Коцюбинського } & \end{array}$ & $5-8$ & 480 & 54 & 106 & 48 & - & $\begin{array}{c}272 \\
(56,7 \%)\end{array}$ \\
\hline 6. & \begin{tabular}{lr}
\multicolumn{2}{l}{ Центральноукраїнський } \\
державний & педагогічний \\
університет & імені \\
Володимира Винниченка
\end{tabular} & $6-8$ & 420 & 82 & 80 & - & 40 & $\begin{array}{c}218 \\
(52 \%)\end{array}$ \\
\hline 7. & $\begin{array}{lr}\text { Глухівський } & \text { національний } \\
\text { педагогічний } & \text { університет } \\
\text { імені } & \text { Олександра } \\
\text { Довженка } & \end{array}$ & $5-7$ & 210 & 32 & 52 & - & - & $\begin{array}{c}126 \\
(60 \%)\end{array}$ \\
\hline 8. & $\begin{array}{l}\text { Південноукраїнський } \\
\text { національний педагогічний } \\
\text { університет } \\
\text { ім. К.Д. Ушинського }\end{array}$ & $5-8$ & 750 & 128 & 256 & - & - & $\begin{array}{c}366 \\
(48,8 \%)\end{array}$ \\
\hline
\end{tabular}

Розвиток самостійності студентів - це один із засобів покращення всього педагогічного процесу та підвищення його ефективності. В умовах всезагального використання інформаційних технологій проблема самостійності та організації самостійної навчально-пізнавальної діяльності студентів виходить на якісно новий рівень. Встановлено, що збільшується ії кількість загалом і порівняно 3 аудиторним навантаженням студентів. Це пояснюється тим, що за системою Європейської кредитно-трансферної системи (ЕСTS) у структурі навчального навантаження студента одним 3 основних компонентів освітньої діяльності стає самостійна робота.

Увага до проблеми розвитку самостійності студентів пояснюється тим, що вона важлива не лише для організації в педагогічних університетах підготовки майбутніх учителів математики на сучасному рівні, а й для формування в них активної позиції, відповідальності, рішучості, оволодіння засобами самоактуалізації, саморозвитку, самоорганізації, самоконтролю та самореалізації. Самостійна робота студентів набуває особливої актуальності в процесі підготовки майбутніх учителів, оскільки такий вид навчально-пізнавальної діяльності вони мають пропагувати в роботі 3 майбутніми вихованцями в закладах загальної середньої освіти.

У процесі дослідження (опитування та бесіди зі студентами та викладачами) з'ясовано, що перші та другі потребують удосконалення та урізноманітнення системи самостійної роботи. У першу чергу, це стосується її планування: визначення цілей та мотивів діяльності; відбір змісту та його конкретизація; пропозиції щодо форм, методів і засобів виконання роботи; характеристика контрольних заходів і критеріїв оцінювання. 
Серія: Педагогічні науки. - Вип.3. - Бердянськ : БДПУ, 2019. - 453 с.

Розглядалося питання про організацію самостійної роботи студентів на основі перспективно-випереджувальної технології 3 використанням IKT.

Спостереження за використанням ІКТ для підготовки майбутніх учителів математики в педагогічних університетах дають підстави стверджувати, що суб'єкти навчання використовують як апаратні засоби інформатизації (комп'ютер, принтер, сканер, модем і ін.), призначені для кодування, обробки, зберігання й передачі інформації в цифровій формі, так і програмні засоби інформатизації - програми, що мають різні функції й призначення та управляють роботою комп'ютера. На основі аналізу та порівняння кількісних характеристик щодо використання апаратних і програмних засобів навчання студентами та викладачами можна зробити висновок про те, що програмні засоби інформатизації більшою мірою використовують студенти, ніж викладачі.

Крім того, під час проведення опитування студентів та викладачів на запитання "Яким засобам навчання ви надаєте перевагу у освітній діяльності: традиційним; інноваційним?” отримали результати, які наведено на рис.1-2.

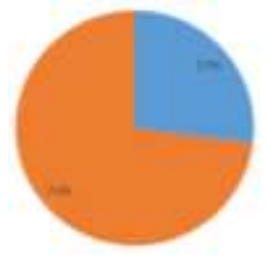

Рис. 1. Результати опитування студентів

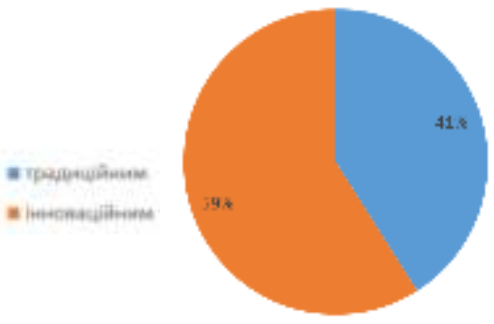

Рис. 2. Результати опитування викладачів

Для організації ефективної самостійної роботи студентів та формування в них фрахових компетентностей було запропоновано використати такі форми, методи та засоби навчання, які подавали б його у цікавій та зручній формі, робили б навчання захоплюючим та мотивували студентів до навчання.

На основі спостереження за процесом навчання встановлено, що молоді люди постійно відчувають брак часу. Це суттєво впливає на якість їхньої підготовки до майбутньої педагогічної діяльності. Сучасні студенти педагогічних університетів мають не тільки добре опанувати дисципліни математичного та методичного циклу, ознайомитися 3 новими нормативними документами та підручниками для різних класів, а й опанувати інноваційні підходи до організації процесу навчання математики в закладах освіти різних рівнів. Для цього їм потрібно багато читати і писати, слухати й переглядати, вчити й повторювати, а також 
виконувати велику кількість різноманітних пізнавальних дій, залучаючи всі складові сенсорної системи (органи чуття, що забезпечують: зір, слух, нюх, смак, дотик тощо). У той же час молоді люди сьогодні серйозно переймаються питаннями фінансового стану, власного здоров'я, особистісних стосунків тощо. На все це використовується не мала кількість часу і власних ресурсів.

Підтримуємо думку О. Жерновникової про доцільність створення та реалізації дистанційних освітніх технологій у процес навчання майбутніх учителів математики через платформу Moodle, яка $€$ автоматизованою, заснованою на комп'ютерних та інтернет-технологіях системою керування навчання. У своїй основі система керування навчання дає викладачеві можливість створити веб-сайт курсу й управляти доступом до нього так, щоб студенти мали можливість переглядати його. Крім контролю доступу, система надає широкий набір інструментів, які зроблять навчальний курс ефективнішим. Викладач на власний розсуд завантажує на сервер плани своїх курсів, замітки щодо лекцій, додатків, завдання для читання, щоб студенти могли використовувати їх у будь-який зручний момент (Жерновникова, 2017: 222).

Для інтенсифрікації підготовки майбутніх учителів математики на основі ефективної самостійної роботи запропоновано осучаснити та адаптувати дві відомі технології - перспективно-випереджального та програмованого навчання. Основна ідея - за допомогою відкритих онлайн курсів та інших сервісів (подкасти, інтерактивна стрічка часу, електронні посібники з використанням ігрових технологій (квестпосібники) тощо) виносити на самостійне опрацювання студентами окремих навчальних тем, випереджаючи їх вивчення в аудиторії.

Розкриємо детальніше засоби реалізації запропонованих технологій та результати їх використання під час підготовки майбутніх учителів математики.

Результати та дискусії. Одним із сучасних засобів візуалізації, які ефективно використовуються В процесі навчання математичних дисциплін, $є$ інтерактивні стрічки часу. Загалом, стрічка часу відображення подій у хронологічному порядку, інтернет сервіси, призначені для відображення історичних подій із додаванням фото, аудіо та відеоматеріалів.

Зарубіжні науковці Е. Курсун, К. Чагілтай (Engin Kursun, \& Kursat Cagiltay, 2007) вважають, що зі збільшенням продуктивності комп'ютерної техніки та роздільної здатності моніторів роль візуальної інформації та графічних інтерфейсів стає все значнішою, зокрема стрічка часу чи інші інтерактивні графічні комп'ютерні технології можуть знизити навантаження на пам'ять людини.

Для створення інтерактивних стрічок часу в процесі навчання математичних дисциплін є досить популярними такі сервіси: Tiki-Toki, Sutori, Preceden, SmartDraw, Timeline JS.

Вивчення в педагогічних закладах вищої освіти таких курсів як “Історія математики", "Історія та методологія математики" будується на 
встановленні локалізації подій у часі та просторі. Крім того, більшість математичних дисциплін передбачає короткий історичний екскурс щодо розвитку цієї дисципліни, ознайомлення із творчим шляхом науковців, а також із датами відкриттів чи публікації наукових праць тощо. Саме тому під час підготовки майбутніх учителів математики доцільно використовувати інтерактивні стрічки часу.

Нами була створена стрічка часу "Історія розвитку лінійної алгебри" (рис. 3) за допомогою сервісу Timeline JS, який, на нашу думку, чудово може бути використаний при створенні стрічок 3 інших математичних дисциплін.

Цей сервіс має значну кількість переваг над іншими, серед яких назвемо такі: стрічка часу створюється за допомогою використання електронної таблиці Google Excel, яка згодом “конвертується" системою, що відкриває переваги користування Google документами (запобігання втрати даних, спільний доступ до проекту); безкоштовний доступ та можливість створювати стільки стрічок часу, скільки дозволяє пам'ять сховища даних; сервіс має інтуїтивно зрозумілий інтерфейс; відображення шкали часу на українській мові; проєктом легко ділитися із іншими; для відображення стрічки часу, крім браузера, не потрібно встановлювати додаткове програмне забезпечення.

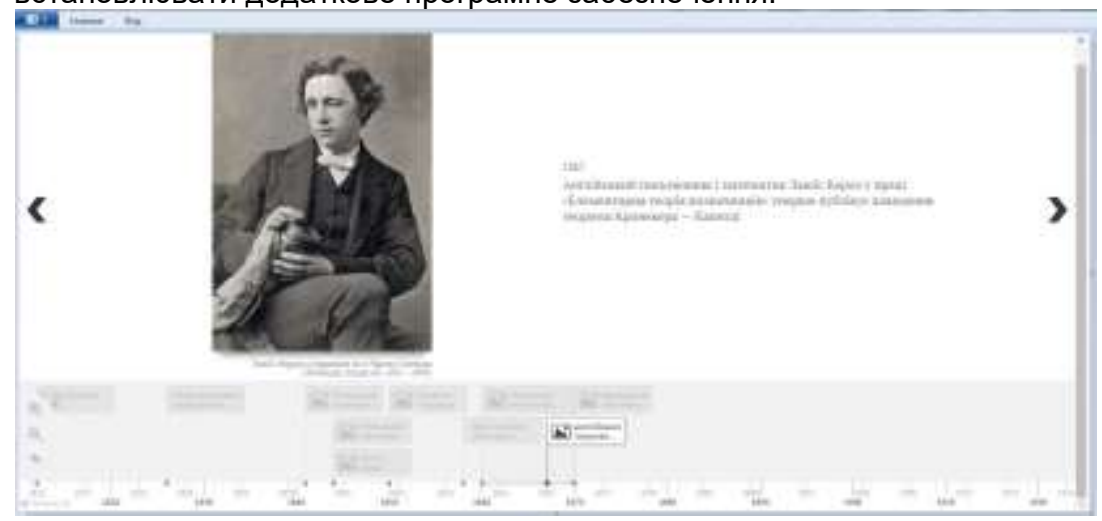

Рис. 3. Фрагмент стрічки часу “Історія розвитку лінійної алгебри"

Проте $є$ й недоліки створення стрічок часу за допомогою сервісу Timeline JS, які планують використовувати під час викладання математичних дисциплін: відсутність редактора формул; відсутність можливості вбудовувати гіперпосилання; відсутність можливості вбудовувати 3D моделі; відображення одночасно не більше трьох подій одного часового проміжку; вузьке коло можливостей фрорматування тексту.

Наші дослідження показали, що інтерактивну стрічку часу можна використовувати як своєрідний план навчання математичних дисциплін. 3 цією метою нами будо створено стрічку часу "Структура курсу методики навчання математики". Вона передбачає чітку часову межу (з 1 вересня 
до закінчення навчального року) з відображенням на ній тем лекцій із коротким планом, тем семінарських та лабораторних робіт із завданнями (рис. 4).

Така попередня форма представлення структури і змісту майбутньої навчальної діяльності, визначеної ув цілях і завданнях, дуже важлива для прогнозування особистої діяльності під час навчання і пошуку необхідної інформації як серед наданої у курсі, так і за межами їі. Така стрічка часу стане стимулом для організації навчання за технологією перспективно-випереджувального навчання, а також надійним помічником для студентів, які навчаються на заочні формі навчання та за індивідуальним планом.

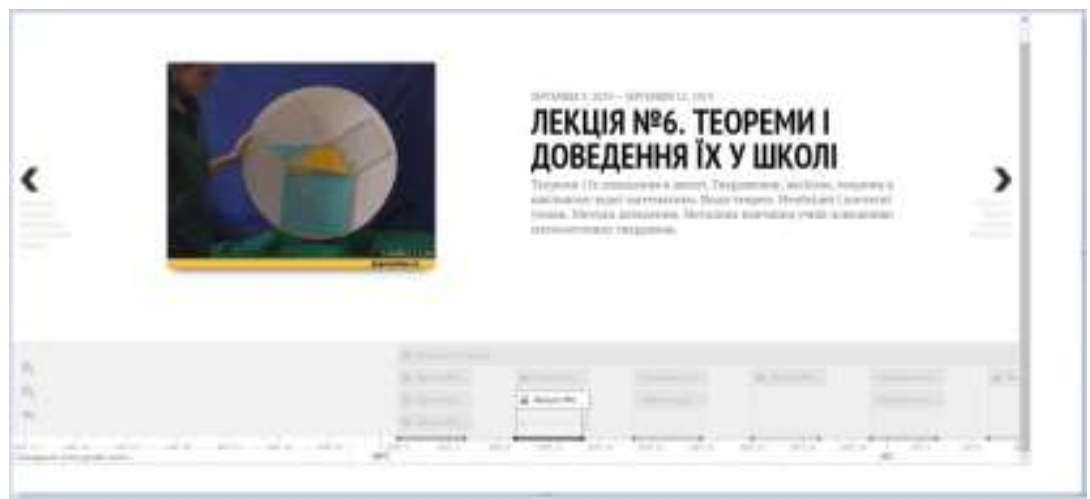

\section{Рис. 4. Фрагмент стрічки часу “Структура курсу методики} навчання математики"

Отже, інтерактивна стрічка часу - сучасний і ефективний засіб навчання, який сприяє забезпеченню якості викладання математичних дисциплін у педагогічних університетах, кращому засвоєнню знань студентами та підвищенню інтересу до навчального предмета.

Цікавим та ефективним у підготовці майбутніх учителів математики, на нашу думку, може стати впровадження в освітній процес навчальних подкастів.

Термін подкасm (PodCast) походить від назви популярного музичного плеєра (iPod) і дієслова Broadcast (передача, трансляція). У початковому значенні подкаст - це трансляція музики в інтернеті за принципом тематичної радіостанції. Такий подкаст складається з низки композицій, які транслюються на спеціальному сайті. 3 часом сфера використання подкастів суттєво розширилася - від огляду художніх фільмів через тематичні зустрічі 3 політиками до уроків 3 англійської мови. Сьогодні подкасти стають зручним способом самоосвіти та відпочинку. Розглянемо детальніше навчальні подкасти та їх використання.

Аналіз інтернет і радіо ресурсів на предмет наявності навчальних подкастів дає підстави стверджувати, що на сьогодні найбільш ICV 2018: 77.58 
уживаними та розповсюдженими є ті, які присвячені вивченню англійської та інших іноземних мов. Вони дуже різні як за стилем подання та змістом, так і за призначенням і тривалістю. Об'єднує їх те, що вони побудовані у формі розповідей, а тому слухач вивчає мову та запам'ятовує мовні конструкції не з правил, а на практиці, знаходячись у відповідному середовищі. Інші подкасти, які можна віднести до навчальних, стосуються історії, фрілософії, загальної культури, бізнесу, фрінансів, сучасних технологій тощо.

В умовах постійного браку часу та збільшення інформації подкасти це чудовий спосіб урізноманітнити та інтенсифікувати навчання майбутніх учителів. Студенти зможуть не тільки швидко отримати потрібні відомості, але й на власному досвіді переконаються в доцільності використання подкастів під час навчання математики в школі для цікавого доповнення навчального матеріалу з підручника. Більше того - студенти можуть спробувати самостійно створювати тематичні подкасти.

Тематика і тривалість подкастів для майбутніх учителів математики може бути різною. Наприклад, з історії математики можна створити аудіо міні-програми, присвячені видатним особистостям (їх тривалість може бути від 5 до 10 хвилин). Довші подкасти (10 -15 хвилин) можуть стосуватися історії розвитку окремих математичних теорій та їх локалізації в часі та просторі.

Подкасти з математичного аналізу, алгебри та теорії чисел, лінійної алгебри, аналітичної геометрії, теорії ймовірностей та інших математичних дисциплін можуть будуватися на теоретичних питаннях і містити основні означення та теореми з конкретної теми. Їх можна слухати в транспорті, під час сніданку, на перерві, в спортзалі та перед сном.

I все ж для навчання майбутніх учителів найбільш актуальними є подкасти з методики навчання математики. Можна створити добірки (по 5 - 10 файлів) такої, наприклад, тематики:

- Нормативні документи, що стосуються освіти та навчання математики.

- Альтернативні підручники математики.

- Інноваційні та традиційні засоби навчання.

- Активні та інтерактивні методи навчання.

- Урізноманітнення фрорм навчання математики.

- Види і функції задач з математики.

Отже, подкасти - це сучасна фрорма передачі та засвоєння актуальної для слухача інформації, а тому їх варто створювати та впроваджувати.

Наше дослідження показало наявність успіхів студентів майбутніх учителів математики в умовах використанням освітніх технологій. Запропоновані засоби можна використовувати для підготовки й інших фахівців.

B. П. Cлагаемьература

В. П. Беспалько. - М. : Педагогика, 1989. - 191 с.

2. Герасименко І. Використання технологій дистанційного навчання / 


\section{Наукові записки БДПУ (http://bdpu.org/pedagogy/ua/)}

І. Герасименко // Вісник Національного університету «Львівська політехніка» Серія: Інформатизація вищого навчального закладу. - Львів: Видавництво Львівської політехніки, 2016. - № 853. - С. 23-30.

3. Гончаренко С. У. Український педагогічний словник / С. У. Гончаренко. - К. : Либідь, 1997. - 375 с.

4. Дичківська І. М. Інновааційні педагогічні технології : Навч. Посібник / І. М. Дичківська. - К. : Академвидав, 2004. - 352с.

5. Жерновникова О. А. Психологічний аспект реалізації дистанційних освітніх технологій у навчальний процес майбутніх учителів математики / О. А. Жерновникова. [Електронний ресурс] // Наукові записки Бердянського державного педагогічного університету. Сер. : Педагогічні науки. - 2017. - Вип. 2. C. 219 - 225. - Режим доступу: http://nbuv.gov.ua/UJRN/nzbdpu_2017_2_34.

6. Кларин М.В.Педагогическая технология в учебном процессе. Анализ зарубежного опыта / М. В. Кларин. - М. : Знание, 1989. - 80 с.

7. Нісімчук А.С. Сучасні педагогічні технології : навч. Посібник / А. С. Нісімчук, О. С. Падалка, О. Т. Шпак. - К. : Просвіта, 2000. - 368 с.

8. Педагогічні технології: теорія та практика: Навчально-методичний посібник / За ред. проф. М.В.Гриньової. - Полт. держ. пед. ун-т ім. В. Г. Короленка. - Полтава, АСМІ: 2006. - 230 с.

9. Підготовка майбутнього вчителя до впровадження педагогічних технологій / [Балицький О.І., Будак В. Д., Манькусь І. В. та Ін.]; за ред. І. А. Зязюна, О. М. Пєхоти. - Київ, 2003. - 240 с.

10. Підласий І. П. Практична педагогіка або три технології. Інтерактивний підручник для педагогів ринкової системи освіти / І. П. Підласий. - Київ : Слово, 2006. - 616c.

11. Селевко Г. К. Энциклопедия образовательных технологий: в 2 т. / Г. К. Селевко. - Москва : НИИ школьных технологий, 2006. - Т.1. - 816 с.

12. Сисоєва С. О. Технології педагогічної творчості в системі освітніх технологій. Освітні технології у школі та вузі (До 210-річчя заснування м. Миколаєва) / С. О. Сисоєва. - Київ : ІЗМН, 1998. - С. 287 - 293.

13. Триус Ю.В. Комп'ютерно-орієнтовані методичні системи навчання математики : Монографія /Ю. В. Триус. -Черкаси : Брама-Україна. -2005 - 400 с.

14. Bitter G. G. Using technology in the classroom / G. G. Bitter, M. E. Pierson. - [6th ed]. - New York: Pearson Education, 2005. - 345 p.

15. Cagiltay K. An examination of two types of timeline, linear vs. staggered: a mixed method approach / K. Cagiltay, E. Kursun // Young researchers for the European future: 3rd technology-enhanced learning enlargement workshop, 28 Jul. 2007. Bulgaria. - Retrieved from : https://telearn.archives-ouvertes.fr/hal-00190070/document

16. Grismore B. Mini technology manual for schools: an introduction to technology integration / Brian A. Grismore // ERIC. - 2012. Retrieved from: https://files.eric.ed.gov/fulltext/ED533378.pdf.

17. Seels B. Instructional technology: The definition and domains of the field / B. Seels, Rita Richey. - Washington DC : Association for Educational Communications and Technology, 1994. - $186 \mathrm{p}$.

18. Wiske M. S. Teaching for understanding with technology /M. S. Wiske, K. R. Franz, L. Breit, - San Francisco: Jossey-Bass, 2005. - 180 p.

\section{References}

1. Bezpalko, V.P. (1989). Slagaemyie pedagogicheskoy tehnologii [The Term of Pedagogical Technology]. Moscow: Pedagogika. [In Russian].

2. Bitter, G. G., \& Pierson, M. E. (2005). Using technology in the classroom (6th ed.). New York: Pearson Education. [In English]. 
3. Cagiltay K., \& Kursun E. (2007). An examination of two types of timeline, linear vs. staggered: a mixed method approach. In 3 rd Technology-Enhanced Learning Enlargement Workshop: Young researchers for the European future. Bulgaria. Retrieved from https://telearn.archives-ouvertes.fr/hal-00190070/document. [In English].

4. Dychkivska, I. M. (2004). Innovaatsiini pedahohichni tekhnolohii: Navch. Posibnyk [Innovative Pedagogical Technologies: Education Manual]. Kyiv: Akademvydav. [In Ukrainian].

5. Grismore, B. (2012). Mini technology manual for schools: an introduction to technology integration. ERIC. Retrieved from: https://files.eric.ed.gov/fulltext/ ED533378.pdf. [In English].

6. Herasymenko, I. (2016). Vykorystannia tekhnolohii dystantsiinoho navchannia [The Use of Distance Learning Technologies]. Visnyk Natsionalnoho universytetu "Lvivska politekhnika». Seriia: Informatyzatsiia vyshchoho navchalnoho zakladu. - Lviv : Vydavnytstvo Lvivskoi politekhniky, 853, 23-30. [In Ukrainian].

7. Honcharenko, S.U. (1997). Ukrainskyi pedahohichnyi slovnyk [Ukrainian Pedagogical Dictionary]. Kyiv: Lybid. [In Ukrainian].

8. Hrynova M. V. (Ed.) (2006). Pedahohichni tekhnolohii: teoriia ta praktyka: Navchalno-metodychnyi posibnyk [Pedagogical Technologies: Theory and Practice: Education Manual]. Poltava: ASMI. [In Ukrainian].

9. Klarin, M. V. (1989). Pedagogicheskaya tehnologiya v uchebnom protsesse. Analiz zarubezhnogo opyita [Pedagogical Technology in the Educational Process. Analysis of Foreign Experience]. Moscow: Znanie. [In Russian].

10. Nisimchuk, A. S., \& Shpak, O. T. (2000). Suchasni pedahohichni tekhnolohii: navch. posibnyk [Modern Pedagogical Technologies: Education Manual]. Kyiv: Prosvita. [In Ukrainian].

11. Pidlasyi, I. P. (2006). Praktychna pedahohika abo try tekhnolohii. Interaktyvnyi pidruchnyk dlia pedahohiv rynkovoi systemy osvity [Practical Pedagogy or Three Technologies. An Interactive Textbook for Educators of the Market System of Education]. Kyiv: Slovo. [In Ukrainian].

12. Seels, B. B., \& Richey, R. C. (1994). Instructional technology: The definition and domains of the field. Washington DC: Association for Educational Communications and Technology. [In English].

13. Selevko, G. K. (2006). Entsiklopediya obrazovatelnyih tehnologiy [Encyclopedia of Educational Technologies]. G. K. Selevko (Ed.). (Vol.2). Moscow: NII shkolnyih tehnologiy. [In Russian].

14. Sysoieva, S. O. (1998) Tekhnolohii pedahohichnoi tvorchosti v systemi osvitnikh tekhnolohii. Osvitni tekhnolohii u shkoli ta vuzi (Do 210-richchia zasnuvannia m. Mykolaieva) [Technologies of Pedagogical Creativity in the System of Educational Technologies. Educational Technologies in School and High School (To the 210th Anniversary of the Foundation of Mykolayiv City)]. Kyiv: IZMN. [In Ukrainian].

15. Tryus, Yu.V. (2005). Kompiuterno-oriientovani metodychni systemy navchannia matematyky: Monohrafiia [Computer-oriented Methodical Systems of Mathematics Teaching: Monograph]. Cherkasy : Brama-Ukraina. [In Ukrainian].

16. Wiske, M. S., Franz, K. R., \& Breit, L. (2005). Teaching for understanding with technology. San Francisco, CA: Jossey-Bass. [In English].

17. Zhernovnykova, O. A. (2017). Psykholohichnyi aspekt realizatsii dystantsiinykh osvitnikh tekhnolohii u navchalnyi protses maibutnikh uchyteliv matematyky [Psychological Aspect of Implementation of Distance Education Technologies in the Educational Process of Future Mathematics Teachers]. Naukovi zapysky Berdianskoho derzhavnoho pedahohichnoho universytetu. Ser.: Pedahohichni nauky, 2, 219-225. Retrieved from http://nbuv.gov.ua/UJRN/nzbdpu. [In Ukrainian]. 
18. Ziaziuna, I., \& Piekhoty O. (Ed). (2003). Pidhotovka maibutnoho vchytelia do vprovadzhennia pedahohichnykh tekhnolohii [Preparing the Future Teacher for the Introduction of Pedagogical Technologies]. Kyiv: A.S.K. [In Ukrainian].

\section{АНОТАЦІЯ}

В інформаційному світі під час навчання студенти мають за невеликі проміжки часу пропускати через себе велику кількість інформації та дифреренціювати ії відповідно до вимог, потреб і бажань суб'єктів освітнього процесу. Саме тому домінантною ознакою навчально-пізнавальної діяльності майбутнього вчителя математики має стати глибоке знання та розуміння всіх механізмів процесу навчання, тобто технологічність - досягнення поставленої мети на основі використання раціональної системи дій викладача $i$ студентів (вчителя та учнів).

Одна з перших технологій в освіті - програмоване навчання - з'явилася в середині минулого століття. Характерними рисами цієї технології $\epsilon$ чітке формулювання навчальної мети та надання алгоритму ї̈ досягнення. Ще одна технологія бере свій початок з середини минулого століття - це технологія перспективно-випереджального навчання. Основна ідея цієї технології створення комфортного освітнього середовища й умов для забезпечення успіху в навчанні. Обидві ці технології відносяться до педагогічних технологій на основі ефективності управління та організації процесу навчання.

Особливої актуальності в процесі підготовки майбутніх учителів набуває самостійна робота студентів, оскільки такий вид навчальнопізнавальної діяльності вони мають пропагувати в роботі з майбутніми вихованиями в закладах загальної середньої освіти. Тому, в контесті дослідження розглядалося питання про організацію самостійної роботи студентів на основі перспективно-випереджувальної технології 3 використанням IKT.

Для інтенсифрікації підготовки майбутніх учителів математики на основі ефективної самостійної роботи запропоновано осучаснити та адаптувати дві відомі технології - перспективно-випереджального та програмованого навчання. Основна ідея - за допомогою відкритих онлайн курсів та інших сервісів (подкасти, інтерактивна стрічка часу, квест посібники тощо) виносити на самостійне опрацювання студентами окремих навчальних тем, випереджаючи їх вивчення в аудиторії.

Ключові слова: майбутні вчителі математики, педагогічні технології, самостійна робота, перспективно-випереджувальна технологія, програмоване навчання, подкасти, стрічка часу. 